\title{
Models of entrepreneurs' participation in economic development of Russian Far East
}

\author{
Vladimir Smirnov \\ School of Economics and Management, \\ Far Eastern Federal University (FEFU) \\ Vladivostok, Russia \\ smirnov.vp@dvfu.ru
}

\begin{abstract}
Entrepreneurial structures make a significant contribution to the social and economic development of the regions. The concept of territorial development of the Russian Far East changes. Models of participation of business structures in the implementation of the program for the development of the region are becoming more complicated. The article substantiates the need to take into account the diversity of models of entrepreneurship participation in the social and economic development of territories. Three models of entrepreneurs' participation in the economic and social development of the Russian Far East are possible. They correspond to three options for assessing and stimulating such participation by various levels of government. The first model has a solid legal basis. The second model reflects the results achieved in the development of entrepreneurship in a market economy. The third model is based on the current understanding of entrepreneurship. The analysis of possible models is supplemented by their synthesis on the foundation of the general economic basis of entrepreneurship. The creation of new capital is such common economic basis for entrepreneurship. Entrepreneurs operating within the framework of the first model create predominantly new productive capital. For its creation, they should receive the appropriate assessment and support of the state. Entrepreneurs operating under the second model create a new capital of all kinds (productive, financial, intellectual). For this, they should receive a higher appreciation and more significant support of the state. Entrepreneurs, operating under the third model, create predominantly new intellectual capital. They deserve maximum evaluation and maximum support from the state.
\end{abstract}

Keywords - the Russian Far East, economic development, entrepreneurship, the creation of new capital.

\section{INTRODUCTION}

The concept of development of the Far East of Russia in recent years has been substantially updated. The State Program of the Russian Federation "Social and Economic Development of the Far East and the Baikal Region", approved by RF Government Resolution No. 308 of April 15, 2014, reflects these updates. Non-commodity exports, the creation of a favorable investment climate, the growth of business activity, the development of small and medium-sized enterprises, the creation of areas of advancing socio-economic development are new landmarks.

Socio-economic development of the Russian Far East is carried out in close connection with the development of Baikal region. Accordingly, the Far East and the Baikal region are united in the macro-region as a special structure. In this formation, as the researchers note [1, p. 119-120], the position of the component parts varies considerably that requires a special approach to each of them by the Federal and regional authorities.

But at the same time, the priorities of the center's policy regarding the implementation of the state program for social and economic development of the Far East and the Baikal region remain unified for the whole macroregion. The program is implemented with two goals.

The first goal of the program is to increase the level of social and economic development of the territory.

The second goal of the program is to meet the need for labor resources and the consolidation of the population in the Far East.

To achieve the objectives of the program, the relevant tasks must be accomplished. The creation of conditions for sustainable development of the territory; increasing the level of investment activity; creation of 103.3 thousand new jobs, including 16.42 thousand of high-performance jobs; the growth of the population of the macroregion to 11.2 million people; development of transport potential are expected to be socio-economic results of solving these problems by 2025 .

Domestic and foreign entrepreneurs take part in the formation of a new concept for the development of the region, the achievement of the priorities of state policy, the realization of the goals and the solution of the set tasks, along with the federal center, subjects of the federation and municipal entities. It is expected that their number will grow, quality characteristics will change. Therefore, their position in the economic system and the conditions of activity should be precisely defined and correctly understood by both the participants themselves and the regulatory bodies. The entrepreneurs can realize the emerging opportunities in various ways, spontaneously or in an organized way. Historical experience and scientific research show that "the concept of entrepreneurship is broadened and fundamental 
principles of entrepreneurship are complemented at different stages of the development of a market economy" [2, p. 14]. So, China has been demonstrating positive experience of spontaneous realization of opportunities already for several decades. R. Coase and N. Wang evaluate this experiment as follows: «...the peasants in the countryside and the unemployed in cities quickly took advantage of economic freedoms to engage in private enterprise. The rise in the private sector became the main engine of economic growth in the 1980s and beyond» [3]. On the other hand, the governments of many countries successfully develop and implement economic policy instruments that make it possible to involve a wide range of entrepreneurs in solving social and economic problems. O. Soskin assesses the use of a variety measures in economic policy with regard to entrepreneurship by the example of Austria [4]. At the same time, experts pay attention to the growing danger of "undermining national entrepreneurship" [5].

\section{RESULTS AND DISCUSSION}

There are three models of business involvement in economic and social development of the Russian Far East and, accordingly, three variants of the evaluation and stimulation of such participation of the federal, regional and municipal authorities after the Federal Law of 29.12.2014, № 473-FZ "On the territories of advancing Social and economic development in the Russian Federation" and other normative legal acts entered into force.

The first model has a solid legal basis. According to the Civil code of the Russian Federation, the entrepreneurship implies an independent activity carried out at one's own risk; activities aimed at gaining systematic profit from the use of property, sale of goods, performing works or rendering services by the persons, registered in the manner prescribed by law. Accordingly, all legal entities (commercial and non-profit organizations) and individual entrepreneurs who have passed state registration and are engaged in break-even activity can be considered as entrepreneurs.

This approach leads to a complete identification of entrepreneurship with business; however, experts propose distinguishing these concepts. N.E. Egorova and G.B. Kleiner write: "If the business as a whole allows one to perform a significant part of the routine activities carried out according to certain specified rules, then economic innovations and pioneer strategic decisions are necessary conditions and an expression of the" spirit "of entrepreneurship... Entrepreneurship in the broadest sense is identified with any business; in a narrow sense - with high-risk types of business associated with the implementation of a significant and, as a rule, a new idea "[6]. According to R. Scase, the entrepreneur's goals are profit and growth, but the businessperson is primarily interested in preserving income [7].

Nevertheless, this model can be applied to a limited number of economic entities, involved in the economic and social development of the territory, namely for small and medium-sized businesses. To distinguish these groups, the criteria for the assignment of economic entities to micro, small and medium-sized enterprises, established by Federal Law No. 209-FZ of July 24, 2007, "On the Development of Small and
Medium-Sized Enterprises in the Russian Federation", are used. Small and medium-sized businesses are subject to other provisions of this law, as well as other changes in Russian legislation, aimed at improving the regulatory and legal regulation of small and medium-sized enterprises. In recent years, a set of measures has been developed and implemented in this area. Improved special tax regimes with the allocation of a tax system based on a patent in a special tax regime. The result is the creation of a fixed source of income at the municipality level. This increases the interest of local authorities in creating favorable conditions for the development of small business in their territory. There is a reduction in the insurance burden for individual entrepreneurs. A legislative basis has been created to simplify the procedure for conducting cash transactions by small enterprises. The legislative act, allowing one to simplify the order of the repayment of the state and municipal property by subjects of small and average business, is accepted. The participation of small business entities in the performance of state and municipal orders was ensured. The criteria for assigning economic entities to the category of small and medium-sized business entities have been clarified. The institution of the Commissioner for the Protection of the Rights of Entrepreneurs was formed.

An important direction is the financial support of small and medium-sized businesses in the Russian Federation, which is gradually turning into a system. Elements of this system are the following programs:

1) a program of support of small and medium-sized enterprises in the agro-industrial complex, implemented by the Ministry of Agriculture of Russia;

2) the program of rendering assistance to self-employment of unemployed citizens, implemented by the Ministry of Labor of Russia;

3) a set of measures aimed at supporting small and medium-sized enterprises in the scientific and technical sphere, implemented by the Foundation for Promoting the Development of Small Forms of Enterprises in the Scientific and Technical Sphere;

4) the federal financial program for supporting small and medium-sized businesses, implemented by the Ministry of Economic Development of Russia;

5) programs of concessional lending and guarantees provided by Vnesheconombank.

Additional measures to support small and medium-sized businesses have been put in place. First, these are measures aimed at creating conditions for the reduction of informal employment in the sphere of small and medium-sized businesses. Secondly, this is the creation of conditions for the development of new market niches by small and mediumsized companies. Thirdly, it is ensuring access of small and medium-sized enterprises to credit resources. Fourth, this is improving the system of providing state support to small and medium-sized enterprises.

However, the results of all these progressive changes apply to both small and medium-sized enterprises, which are the 
goals of profit and growth, and to the representatives of small and medium-sized businesses who are interested primarily in maintaining income.

The second model reflects the results achieved in the development of entrepreneurship in a market economy. Russian researchers analyze foreign experience and distinguish four waves in the process of developing the theory of the entrepreneurial function: 1) study of risk taking by entrepreneurs; 2) highlighting innovation in entrepreneurship; 3 ) the study of a particular sensitivity of the entrepreneur in the detection and use of unknown opportunities to others; 4) a combination of management mechanisms of the company of any size and entrepreneurial principle [8]. Entrepreneurship in this case is recognized as a risky, innovative activity that owners, managers and even hired workers (in the latter case, they speak of internal entrepreneurship or intrapreneurship), who find and use unknown opportunities to others, can lead. This definition of entrepreneurship corresponds to the understanding that was developed in developed countries by the end of the twentieth century. Small, medium and large business entities that meet these characteristics should be considered as entrepreneurial structures and receive state support.

The third model is based on the understanding of entrepreneurship, that is only taking shape in modern conditions. This understanding is formed by leading foreign experts in the field of economic theory, management theory, management, sociology, psychology. W. Gartner and S. Shane [9], as well as P. Reynolds and E. Autio [10] believe that entrepreneurship is the creation of new firms. P. Davidson, F. Delmar and J. Wicklund put forward the proposition that entrepreneurship is the creation of new types of economic activity [11]. T. T. Aldridge and D. Audretsch assess entrepreneurship based on data on technology transfer, as well as use data on the financing of commercialization of innovations [12]. I. Kirtsner believes that entrepreneurship is the search for an opportunity to profit in a situation of economic disequilibrium, and successful entrepreneurial activity leads to the restoration of economic equilibrium [13]. H. Stephenson and J. Jarilo define entrepreneurship as a search for favorable opportunities, regardless of the resources currently controlled [14, p. 23]. S. Venkataraman proposes understanding entrepreneurship as "the discovery and use of profitable favorable opportunities for creating private wealth and, as a consequence, for the creation of social wealth" [15, p. 132]. A new approach is to study the entrepreneurial orientation of firms. G. Lampkin and G. Dess in the list of components of entrepreneurial orientation include "a tendency to act autonomously, readiness for innovation, readiness for risk, striving for aggressive behavior towards competitors and proactive behavior in relation to market opportunities" [16, p. 136 - 137]. The processes of causation and effects in the search and realization of new opportunities in entrepreneurial activity are evaluated [17].

The power structures of Russia are approaching the understanding of these new trends in entrepreneurial activity. The Ministry of Economic Development of Russia together with the autonomous non-commercial organization "Agency of Strategic Initiatives for Promotion of New Projects" and with the business community developed and implemented the National Entrepreneurship Initiative.

The national entrepreneurial initiative includes a set of "road maps", containing plans for priority actions on the most problematic areas of state regulation. Approved "road maps", in particular, provide for: increasing the availability of energy infrastructure; support for access to foreign markets and support for exports; improvement of customs administration; improvement of the business climate in construction; improving the quality of public services in the sphere of state cadastral registration of real estate and state registration of rights to real estate and transactions with them; development of competition and improvement of antimonopoly regulation; optimization of registration procedures for legal entities and individual entrepreneurs; expanding the access of SME entities to the procurement of infrastructure monopolies and companies with state participation; improving the quality of the regulatory environment for business.

The variety of modern approaches to entrepreneurship allows us to identify more fully its characteristics and use the knowledge, gained in practical activities. The positions of leading researchers are converging, but their synthesis does not occur, the fragmentation of the subject field of entrepreneurship is preserved [18]. In order to synthesize the positions of modern researchers and specialists in the field of entrepreneurship, it is necessary to find in their approaches, as well as in various types and forms of entrepreneurship, a common economic basis. Such common economic basis for any entrepreneurship is the creation of new capital by active economic entities (entrepreneurs). Entrepreneurs have the unique ability to create a new capital of various types and shapes at any stage of the production process, in any field of economic activities. To do this, they use and apply not only resources, but also factors, conditions, forms, methods, means and results of activities.

Entrepreneurship in a market economy is "an innovative, accompanied by the risk activity of economic entities, consisting in the creation of new capital... and to obtain ... the various forms of entrepreneurial income. Entrepreneurship is also carried out as transformation (change of shape, direction, methods of application) with the aim to increase the productivity of capital, previously created with the purpose of obtaining business income" [19, p. 2195]. New capital can be embodied in new elements, becoming dominant in its structure, in the course of purposeful transformation of resources, factors, conditions, forms, methods, means, results of economic activity. In each of these areas, entrepreneurship is developing. Accordingly, economic periods differ in periods of dominance of such types of capital as trade, productive, financial and intellectual capital. Within the framework of types of capital, its various forms can be distinguished. Thus, commercial capital exists in the forms of commodity and money capital. Productive capital acts in the forms of fixed and working capital and has a pronounced industry specificity. Financial capital can be own and borrowed capital, as well as operational, investment and speculative capital. The forms of intellectual capital are human, organizational and consumer capital. Different participants of the entrepreneurial process 
realize their interests in different ways, but they must create new capital of any kind or form.

The reasons for the changes in entrepreneurship can be expressed in the following way: this is the growth of contradictions in business under the influence of external and internal factors. Circumstances of a technical, technological, organizational and economic nature may be such causes.

The development of entrepreneurship as a result of changes in technology can be described as follows. The interconnection of progressive processes in industrial and post-industrial society (in its institutional and economic structure, including its element as entrepreneurship) with changes in technology is increasing. This relationship is most striking when it comes to the analysis of the long-wave theory, which is distinguished by the theory of long waves. Kondratieff and J. Schumpeter's theory of economic development of technological structures and technical and economic paradigms. The concept of technological structures is actively developed by S.Yu. Glazyev. He substantiated the existence of special groups of technological aggregates in the structure of the economy. They are connected with each other by the same type of technological chains and form reproducible integrity - technological structures. The technological structure is understood as a holistic and sustainable education, within the framework of which a closed cycle is carried out, including the extraction and production of primary resources, all stages of their processing, and the production of a set of final products that satisfy the appropriate type of public consumption [20].

Entrepreneurship plays an active role in technological development and in the transition from one technological order to another technological order. During the periods of domination of different technological patterns, the behavior of entrepreneurs differs. At the same time, successful practices of past periods are not rejected, but complemented by new procedures.

During the period of domination of the first technological order in the sphere of entrepreneurship, the competition of individual entrepreneurs and small firms, their association into partnerships, ensuring the co-operation of individual capitals, were typical. New capital was created primarily in the form of productive industrial capital.

The second technological structure was characterized by the concentration of production in large organizations, the development of joint-stock companies that ensure the pooling of small capital into large capital on the principles of limited liability. The new capital was created mainly in the forms of productive industrial capital based on organizational and financial operations.

The third technological order was distinguished by mergers of firms, concentration of production in cartels and trusts, dominance of monopolies and oligopolies, separation of management from property. The new capital was created in various forms, but with the predominance of forms of financial capital.

During the period of domination of the fourth technological order in the countries with a market economy, there have been significant changes. Oligopolies have consolidated their position; vertical integration and concentration of production have developed. Divisional hierarchical control began to be applied in the management of firms. Dominance of the technological structure was established in corporations; transnational corporations took the leading positions in the world economy. The creation and use of various forms of intellectual capital (human, organizational, consumer) came to the fore in the entrepreneurial activity.

Distinctive features of the fifth technological order, currently dominant in developed countries, are the combination of production and marketing of products, deliveries "just in time," the international integration of small and medium-sized firms based on information technology. There is further intellectualization of economic activity; the scale of innovative entrepreneurship is expanding. The processes of creating various forms of new capital are crossing national borders. In recent years in the developed countries, moving to the stage of post-industrial development, the sixth technological order is being formed.

The sixth technological order is based on the use of nanotechnology. Its core is nanoelectronics, molecular and nanophotonics, the production of nanomaterials and nanostructured coatings, optical nanomaterials, nanoheterogeneous systems, application of nanobiotechnology, nanosystem engineering, and nanoequipment [21]. Foreign researchers identify the conditions for the formation of an effective nanoeconomy [22]. In the economy, the institutions of credit support for technological renovation of production are being strengthened, and targeted state loans for long-term investments are widely used. Within this technological structure, the main resources and factors of economic development are technological capital and entrepreneurship, based on its application.

Table 1 shows the behavior of entrepreneurs, the types and forms of the new capital that they create under conditions of dominance of various technological structures.

TABLE I. TECHNOLOGICAL STRUCTURE, BEHAVIOR OF ENTREPRENEURS, TYPES AND FORMS OF THE CREATED CAPITAL

\begin{tabular}{|c|c|c|}
\hline $\begin{array}{l}\text { Technological } \\
\text { structures }\end{array}$ & Behavior of entrepreneurs & $\begin{array}{l}\text { Types and forms of the } \\
\text { created capital }\end{array}$ \\
\hline The first & $\begin{array}{l}\text { Competition of individual } \\
\text { entrepreneurs and small firms, } \\
\text { their association in } \\
\text { partnership, ensuring the co- } \\
\text { operation of individual } \\
\text { capitals }\end{array}$ & $\begin{array}{l}\text { Productive industrial } \\
\text { capital }\end{array}$ \\
\hline The second & $\begin{array}{l}\text { Concentration of production } \\
\text { in large organizations, the } \\
\text { development of joint-stock } \\
\text { companies that ensure the } \\
\text { pooling of small capital into } \\
\text { large capital by the principles } \\
\text { of limited liability }\end{array}$ & $\begin{array}{l}\text { The productive industrial } \\
\text { capital, formed on the } \\
\text { basis of organizational } \\
\text { and financial operations }\end{array}$ \\
\hline Third & $\begin{array}{l}\text { Merger firms, } \\
\text { concentration of production in } \\
\text { cartels and trusts, dominance } \\
\text { of monopolies and oligopolies, } \\
\text { separation of management } \\
\text { from property }\end{array}$ & $\begin{array}{l}\text { The diverse forms of } \\
\text { productive and financial } \\
\text { capital, but with the } \\
\text { predominance of forms of } \\
\text { financial capital }\end{array}$ \\
\hline
\end{tabular}




\begin{tabular}{|c|c|c|}
\hline $\begin{array}{l}\text { Technological } \\
\text { structures }\end{array}$ & Behavior of entrepreneurs & $\begin{array}{c}\text { Types and forms of the } \\
\text { created capital }\end{array}$ \\
\hline Fourth & 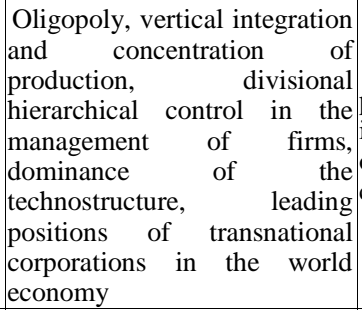 & $\begin{array}{lr}\text { Various } & \text { forms } \\
\text { productive, financial and } \\
\text { intellectual } & \text { (human, } \\
\text { organizational, consumer) } \\
\text { capital }\end{array}$ \\
\hline Fifth & $\begin{array}{l}\text { Association of production and } \\
\text { marketing of products, } \\
\text { supplies "just in time," the } \\
\text { international integration of } \\
\text { small and medium-sized firms } \\
\text { based on information } \\
\text { technology }\end{array}$ & $\begin{array}{c}\text { A variety of forms of } \\
\text { productive, financial and } \\
\text { intellectual capital, which } \\
\text { overcome national } \\
\text { boundaries in the process } \\
\text { of creating }\end{array}$ \\
\hline Sixth & $\begin{array}{l}\text { Strengthening the institutions } \\
\text { of credit support for } \\
\text { technological renewal of } \\
\text { production, wide application } \\
\text { of targeted state loans for } \\
\text { long-term investments }\end{array}$ & $\begin{array}{l}\text { The diverse forms of } \\
\text { productive, financial and } \\
\text { intellectual (primarily } \\
\text { technological) capital, } \\
\text { which overcome national } \\
\text { characteristics in the } \\
\text { process of creating }\end{array}$ \\
\hline
\end{tabular}

Entrepreneurs, operating within the framework of the first model, can operate on a relatively simple base of the first and second technological structures and create predominantly new productive capital. For its creation, they should receive the appropriate assessment and support of the state. Entrepreneurs, operating under the second model, rely on the base of the third and fourth technological structures and create new capital of all kinds (productive, financial, intellectual). For this, they should receive a higher appreciation and more significant support of the state. Entrepreneurs, operating under the third model, create predominantly a new intellectual capital, including such form as technological capital. Such activities deserve maximum evaluation and maximum support from the state.

In the Russian Far East, entrepreneurs create new capital when they take part in foreign economic activity (in the export-import of goods, works and services). The new capital is created as a result of attraction of direct investments. The growth of business activity in any form is accompanied by the creation of new capital. The created new capital in various types and forms allows one to adequately assess the scale and quality of development of small and medium-sized businesses in the region. Without the independent creation of new capital, it is impossible to obtain the status of a resident of the territory of the outpacing socio-economic development and the free port of Vladivostok. A correct definition of models of entrepreneurial activity of participants in these processes and providing them with appropriate support will speed up the solution of complex tasks of social and economic development of the Russian Far East.

\section{CONCLUSION}

Domestic and foreign entrepreneurs together with the federal center, federal subjects and municipalities actively participate in the development of the concept of the development of the Russian Far East, the achievement of the priorities of state policy, the implementation of goals and the solution of tasks. It is assumed that the number of entrepreneurs will grow, and the results of activities will increase. The situation of entrepreneurial structures in the economic system and the conditions for their activities should be precisely defined and correctly understood by both the participants themselves and by the authorities. As a result, the contribution of entrepreneurial structures to the socioeconomic development of the regions can be significantly increased. The study attempted to identify patterns of participation of entrepreneurs in this process and to assess the results of their activities. Three possible models of entrepreneurs' participation in the economic and social development of the Russian Far East are analyzed. It is shown that the conditions for the implementation of these models in a market economy are determined by the level of technological development. With the models of entrepreneurs' participation in economic and social development, three options for assessing and stimulating such participation by various levels of government should be involved.

The analysis of possible models is supplemented by their synthesis based on the general economic basis of entrepreneurship, under which it is proposed to understand the creation by the entrepreneurial structures of new capital in various types and forms. The unique ability of real entrepreneurs to create new capital of various types and forms at any stage of the production process in any sphere of economic activity, not only from resources but also from factors, conditions, forms, methods, means and results of activity is noted. Accordingly, entrepreneurship should not be considered as any revenue-generating activity of market entities. Entrepreneurship is an innovative, risk-driven activity of economic entities, which consists in the creation of new capital with the appropriate conversion of resources, factors, conditions, forms, methods, means and results of economic activity and in obtaining various forms of entrepreneurial income. Entrepreneurship should also recognize the transformation (changing the form, directions, methods of application) of previously created capital to increase its returns and generate additional revenues.

The power structures of Russia are approaching an understanding of new trends in entrepreneurial activity. However, it is easier for them to use established stereotypes and formal criteria. The use of characteristics and indicators of the creation of new capital in a variety of types and forms allows one to identify the growth processes of entrepreneurial organizations, to measure and to assess the level of entrepreneurship development in various spheres, regions and national economy complexes. On the grounds of the creation of new capital, it is necessary to distinguish between traditional business and risky entrepreneurship in order to improve their state and market regulation. Further studies of entrepreneurship should be conducted in this direction.

\section{References}

[1] P.A. Minakir, O.M. Prokapalo, "The state program of the Russian Federation "Social and economic development of the Far East and the Baikal Region"', Space Economy, vol. 1, pp. 103-122, 2013.

[2] V. Smirnov, "The genesis of the entrepreneurship theory at the classical and non-classical stages of science development", Economic AnnalsXXI , vol. 164(3-4), pp. 14-19, 2017. 
[3] R.Coase, N. Wang, How China Became Capitalist, Palgrave Macmillan UK, 2012, p. 161 .

[4] O. I. Soskin, "Economic policy for small and medium business in the framework of the model of national capitalism: the Austrian experience", Journal of European Economy, vol. 11(2), pp. 168-184, 2012.

[5] O. Bilorus, "Replenishment evolution and structural transformation of global capital", Economic Annals-XXI, vol. 155(11-12), pp. 4-9, 2015.

[6] Strategy of Entrepreneurship Development in the Real Sector of the Economy, Moscow, Science, 2002, pp.35-36.

[7] R. Scase, "The role of small businesses in the economic transformation of Eastern Europe: real but relatively unimportant?" International Small Business Journal, vol. 16 (1), pp.13-21, 1997.

[8] A.A. Dynkin, A.R. Sterlin, I.V. Tulin, Entrepreneurship in the Late XX Century, Moscow, Science, 1992, p. 242.

[9] W. B. Gartner, S. A. Shane "Measuring entrepreneurship over time", Journal of Business Venturing, vol. 10 (4), pp. 283-301, July 1995.

[10] P. Reynolds, E. Autio, "Global Entrepreneurship Monitor: Data collection, design and implementation 1998 - 2003", Small Business Economics, vol. 24 (3), pp. 205-231, 2005.

[11] P. Davidson, F. Delmar, J. Wiklund, "Entrepreneurship as growth; growth as entrepreneurship", In: Davidson P., Delmar F., Wiklund J. (eds.). Entrepreneurship and the Growth of the Firms. Edward Elgar Publishing: Cheltenham, UK; Northampton: MA, USA, 2006. pp. 21-35.

[12] T. T. Aldridge, D. Audretsch, "The Bayh-Dole act and scientist entrepreneurship", Research Policy, vol. 40 (8), pp. 1058-1067, October 2011.
[13] I. M. Kirzner, Competition and Entrepreneurship, Chicago: University of Chicago Press, 1973, pp. 48-49.

[14] H. Stevenson, J. Jarillo, "A paradigm of entrepreneurship: Entrepreneurial management", Strategic Management Journal, vol. 11, pp. 17-27, 1990.

[15] S. Venkataraman, "The distinctive domain of entrepreneurship research: An editors perspective", Katz J., Brockhaus J. (eds.), Advances in Entrepreneurship, Firm Emergence, and Growth, vol. 3, JAI Press: Greenwich, CT, 1997, p. 132.

[16] G. T. Lumpkin, G. G. Dess, "Clarifying the entrepreneurial orientation construct and linking it to performance", Academy of Management Review, vol. 21 (1), pp. 135-172, 1996.

[17] S. Sarasvathy, "Causation and effectuation: toward a theoretical shift from economic inevitability to entrepreneurial contingency", Academy of Management Review, vol. 26 (2), pp. 243-263, 2001.

[18] H. Landstrom, G. Harirchi, F. Astrom, "Entrepreneurship: exploring the knowledge base", Research Policy, vol. 41, pp. 1154-1181, 2012.

[19] V. Smirnov, "Entrepreneurship as the creation of the new capital", Journal of Advanced Research in Law and Economics, vol. VII, 8(22), pp. 2192-2200, Winter 2016.

[20] S. Glazyev, The Theory of Long-term Technical and Economic Development, Moscow, Vlada Dar, 1993, 30 p.

[21] S. Glazyev, "The world economic crisis as a process of changing technological structures", Issues of Economics, vol. 3, p. 26-38, 2009.

[22] M. Allarakhia, S. Walsh, "Analyzing and organizing nanotechnology development: application of the institutional analysis development framework to nanotechnology consortia", Technovation, vol. 32 (3-4), pp. 216-226, March-April 2012. 